\title{
Antiproliferative Compounds from Ocotea macrocarpa from the Madagascar Dry Forest ${ }^{1}$
}

Yixi Liu ${ }^{a}$, Emily Cheng ${ }^{a}$, L. Harinantenaina Rakotondraibe ${ }^{\mathrm{a}, \mathrm{f}}$, Peggy J. Brodie ${ }^{\mathrm{a}}$, Wendy Applequist ${ }^{\mathrm{c}}$, Richard Randrianaivo $^{\mathrm{d}}$, Andriamalala Rakotondrafara ${ }^{\mathrm{d}}$, Michel Ratsimbason ${ }^{\mathrm{e}}$, Vincent E. Rasamison ${ }^{\mathrm{e}}$ and David G. I. Kingston ${ }^{\mathrm{a},} *$

${ }^{a}$ Department of Chemistry and the Virginia Tech Center for Drug Discovery, Virginia Tech, Blacksburg, Virginia 24061, bDepartment of Biochemistry and Virginia Tech Center for Drug Discovery, M/C 0308, Virginia Tech, Blacksburg, Virginia 24061, ${ }^{c}$ Missouri Botanical Garden, P.O. Box 299, St. Louis Missouri 63166,

${ }^{d}$ Missouri Botanical Garden, Lot VP 31 Ankadibevava, Anjohy Antananarivo 101, Madagascar

${ }^{e}$ Centre National d'Application des Recherches Pharmaceutiques, B.P. 702, Antananarivo 101, Madagascar,

${ }^{f}$ Present address: College of Pharmacy, Division of Medicinal Chemistry and Pharmacognosy, The Ohio State University, Columbus, OH 43210, United States.

\section{ARTICLE INFO ABSTRACT}

\section{Article history:}

Received

Received in revised form

Accepted

Available online

\section{Keywords:}

Antiproliferative activity

Ocotea macrocarpa

Butanolide

Lauraceae

\begin{abstract}
Bioassay-directed fractionation of an antiproliferative ethanol extract of the roots of Ocotea macrocarpa (Lauraceae) afforded the new butanolide macrocarpolide A (1), and the two new secobutanolides macrocarpolides B (2) and C (3), together with the known butanolides linderanolide B (4) and isolinderanolide (5). The structure elucidation of all compounds was carried out based on NMR and mass spectroscopic data analyses. The absolute configurations of all compounds isolated were determined by comparison of their optical rotation values with those found in literature. Compounds $\mathbf{1 - 5}$ showed good antiproliferative activities against the A2780 ovarian cell line, with IC $_{50}$ values of $2.57 \pm 0.12$ (1), $1.98 \pm 0.23$ (2), $1.67 \pm 0.05$ (3), $2.43 \pm 0.41$ (4), and $1.65 \pm 0.44 \mu \mathrm{M}(5)$, respectively.
\end{abstract}

2015 Elsevier Ltd. All rights reserved.
As a part of the Madagascar International Cooperative Biodiversity Group (ICBG) program, ${ }^{2 \mathrm{ab}}$ an ethanol extract of the roots of Ocotea macrocarpa was found to have moderate activity against the A2780 ovarian cancer cell line ( $\left.\mathrm{IC}_{50} 3.9 \mu \mathrm{g} / \mathrm{ml}\right)$. This extract was thus selected for further evaluation for the presence of novel anticancer agents. The plant genus Ocotea, the largest member of the Lauraceae family, comprises approximately 350 species that are distributed throughout tropical and subtropical climates. Most species are found in the Americas from Mexico to Argentina, seven species are found in Africa, one specie is found in the Canary Islands, and about 34 recognized species are found in Madagascar. ${ }^{3 \mathrm{ab}}$ Some species are used in traditional medicine, including for treatment of fever and malaria. ${ }^{4}$ Chemical investigations on various Ocotea species have led to the isolation of a wide range of secondary metabolites including alkaloids, flavonoids, lignans, and terpenoids, many of which exhibited interesting antiproliferative, antifungal, antiherpetic, antiinflammatory, and antimicrobial activities. ${ }^{\text {5abcdefg }}$<smiles>C=CCC=C1C(=O)OC(=C)[C@@H]1O</smiles>

$13 E, 4 S \mathrm{n}=12$ $43 Z, 4 R \mathrm{n}=11$ $53 Z, 4 S \mathrm{n}=13$

Figure 1. Structures of compounds 1-5.

Bioassay-guided isolation of an extract of the roots of Ocotea macrocarpa produced five bioactive compounds: one new butanolide (1), two new secobutanolides (2 and 3), and two known butanolides, linderanolide B (4) ${ }^{6}$ and isolinderanolide (5). ${ }^{7}$ The structures of the known compounds were determined by a comparison of their ${ }^{1} \mathrm{H}$ NMR and mass spectra data with 
literature data, together with a comparison of their optical rotation values with the literature values.

Compound 1 was isolated as a colorless oil. The molecular formula was determined to be $\mathrm{C}_{20} \mathrm{H}_{34} \mathrm{O}_{3}$ by HRESIMS ([M $\left.+\mathrm{H}\right]^{+}$, $m / z$ 323.2586, cal. for $\mathrm{C}_{20} \mathrm{H}_{35} \mathrm{O}_{3}{ }^{+} 323.2581$ ). The IR exhibited the characteristic absorption bands at $3450 \mathrm{~cm}^{-1}$ for a hydroxyl group, and 1760 and $1700 \mathrm{~cm}^{-1}$ for an $\alpha, \beta$-unsaturated- $\gamma$-lactone. ${ }^{8}$ The UV spectrum of $\mathbf{1}$ had an absorption maximum at $226 \mathrm{~nm}$. The IR, UV and ${ }^{1} \mathrm{H}$ NMR spectroscopic data of 1 were comparable to those of $\mathbf{4}$ and $\mathbf{5}$, suggesting that $\mathbf{1}$ had the same $\beta$-hydroxy- $\gamma$ methylene- $\alpha, \beta$-unsaturated $\gamma$-lactone skeleton. The proton signal at $\delta_{\mathrm{H}} 7.10\left(\mathrm{dt}, J=7.8,2.0 \mathrm{~Hz}, 1 \mathrm{H}, \mathrm{H}-1^{\prime}\right)$ in 1 differed significantly from the corresponding signals in $\mathbf{4}$ and $\mathbf{5}$ at $\delta_{\mathrm{H}} 6.68$ (td, $J=7.8,2.0 \mathrm{~Hz}, 1 \mathrm{H}, \mathrm{H}-1^{\prime}$ ), suggesting the $E$ configuration for $\Delta^{3\left(1^{\prime}\right)}$ in $1 .{ }^{89}$ The ${ }^{1} \mathrm{H}$ NMR spectrum of $\mathbf{1}$ also displayed resonances assignable to two exomethylene protons appearing at $\delta_{\mathrm{H}} 4.96$ and $\delta_{\mathrm{H}} 4.72\left(\mathrm{dd}, J=2.8,1.4 \mathrm{~Hz}\right.$, each $\left.1 \mathrm{H}, \mathrm{H}_{2}-6\right)$, one oxymethine at $\delta_{\mathrm{H}} 5.26$ (brs, $\left.1 \mathrm{H}, \mathrm{H}-4\right)$, and two deshielded methylene protons at $\delta_{\mathrm{H}} 2.50$ and $\delta_{\mathrm{H}} 2.43(\mathrm{dt}, J=14.8,7.2 \mathrm{~Hz}$, each $\left.1 \mathrm{H}, \mathrm{H}_{2}-2^{\prime}\right)$. The positions of these protons were assigned from HMBC experimentation (Fig. 2). The exocyclic olefinic signals at $\delta_{\mathrm{H}} 4.96$ and $\delta_{\mathrm{H}} 4.72\left(\mathrm{H}_{2}-6\right)$ were correlated with both a quaternary carbon at $\delta_{\mathrm{C}} 157.8(\mathrm{C}-5)$ and a methine carbon at $\delta_{\mathrm{C}}$ 66.7 (C-4). Carbon 5 also correlated with the oxymethine signal at $\delta_{\mathrm{H}} 5.26(\mathrm{H}-4)$. Furthermore, clear long range correlations between both the oxymethine proton at $\delta_{\mathrm{H}} 5.26(\mathrm{H}-4)$ and the olefinic proton at $\delta_{\mathrm{H}} 7.10\left(\mathrm{H}-1^{\prime}\right)$ to the carbonyl carbon at $\delta_{\mathrm{C}}$ 166.1 (C-2) were observed in the HMBC spectrum.

Table 1. ${ }^{1} \mathrm{H}$ and ${ }^{13} \mathrm{C}$ NMR data for compound $1 .{ }^{\mathrm{a}}$

\begin{tabular}{lll}
\hline Posn & \multicolumn{1}{c}{$\delta_{\mathrm{H}}{ }^{\mathrm{b}}$} & \multicolumn{1}{c}{$\delta_{\mathrm{c}}{ }^{\mathrm{c}}$} \\
\hline 2 & & $166.1(\mathrm{C})$ \\
3 & & $66.7(\mathrm{CH})$ \\
4 & $5.26 \mathrm{brs}$ & $157.8(\mathrm{C})$ \\
5 & & $91.5\left(\mathrm{CH}_{2}\right)$ \\
6 & $4.96 \mathrm{dd}(2.8,1.4)$ & $150.3\left(\mathrm{CH}^{2}\right)$ \\
$1^{\prime}$ & $4.72 \mathrm{dd}(2.8,1.4)$ & $29.8\left(\mathrm{CH}_{2}\right)$ \\
$2^{\prime}$ & $7.10 \mathrm{dt}(7.8,2.0)$ & \\
& $2.50 \mathrm{dt}(14.6,7.7)$ & $28.3\left(\mathrm{CH}_{2}\right)$ \\
$3^{\prime}$ & $2.43 \mathrm{dt}(14.6,7.7)$ & $29.8-29.5\left(\mathrm{CH}_{2}\right)$ \\
$4^{\prime}$ & $1.25-1.31$ & $29.8-29.5\left(\mathrm{CH}_{2}\right)$ \\
$5^{\prime}$ & $1.25-1.31$ & $29.8-29.5\left(\mathrm{CH}_{2}\right)$ \\
$6^{\prime}$ & $1.25-1.31$ & $29.8-29.5\left(\mathrm{CH}_{2}\right)$ \\
$7^{\prime}$ & $1.25-1.31$ & $29.8-29.5\left(\mathrm{CH}_{2}\right)$ \\
$8^{\prime}$ & $1.25-1.31$ & $29.8-29.5\left(\mathrm{CH}_{2}\right)$ \\
$9^{\prime}$ & $1.25-1.31$ & $29.8-29.5\left(\mathrm{CH}_{2}\right)$ \\
$10^{\prime}$ & $1.25-1.31$ & $29.8-29.5\left(\mathrm{CH}_{2}\right)$ \\
$11^{\prime}$ & $1.25-1.31$ & $29.8-29.5\left(\mathrm{CH}_{2}\right)$ \\
$12^{\prime}$ & $1.25-1.31$ & $32.1\left(\mathrm{CH}_{2}\right)$ \\
$13^{\prime}$ & $1.25-1.31$ & $22.8\left(\mathrm{CH}_{2}\right)$ \\
$14^{\prime}$ & $1.25-1.31$ & $14.3\left(\mathrm{CH}_{3}\right)$ \\
$15^{\prime}$ & $1.25-1.31$ & \\
\hline$m^{\prime}$ & $0.88 \mathrm{t}(7.0)$ &
\end{tabular}

assignments based on analysis of 2D NMR spectra.

${ }^{\mathrm{b}}$ Data $(\delta)$ measured at $500 \mathrm{MHz}$; brs = broad singlet, $\mathrm{dd}=$ doublet of doublets, $\mathrm{dt}=$ doublet of triplets. $J$ values are in $\mathrm{Hz}$ and are omitted if the signals overlapped as multiplets. The overlapped signals were assigned from HSQC and HMBC spectra without designating multiplicity.

${ }^{\mathrm{c}}$ Data $(\delta)$ measured at $125 \mathrm{MHz} ; \mathrm{CH}_{3}, \mathrm{CH}_{2}, \mathrm{CH}$, and $\mathrm{C}$ multiplicities were determined by HSQC experiment.

In addition, a broad peak at $\delta_{\mathrm{H}} 1.25-1.31\left(28 \mathrm{H}, \mathrm{H}-3^{\prime}-14^{\prime}\right)$ and a triplet at $\delta_{\mathrm{H}} 0.88\left(J=7.0 \mathrm{~Hz}, \mathrm{H}-15^{\prime}\right)$ were attributed to the methylene protons in a long alkyl chain and the terminal methyl group in $\mathbf{1}$, respectively. Compound $\mathbf{1}$ showed an $[\alpha]^{21}$ value of $-11.11(c 0.27, \mathrm{MeOH})$, indicating the $S$ configuration at C-4 as described for previously reported butanolides. ${ }^{910 a b}$ The complete assignments of all protons and carbons of $\mathbf{1}$ (Table 1) were accomplished by further interpretation of its HMBC and HSQC spectra. Thus, the structure of $\mathbf{1}$ was elucidated as $(3 E, 4 S)-4-$ hydroxy-5-methylene-3-pentadecylidene-dihydro-furan-2-one, and named macrocarpolide $\mathrm{A}$.

Compound 2, a colorless oil, had a molecular formula of $\mathrm{C}_{23} \mathrm{H}_{42} \mathrm{O}_{4}$, as deduced from its HRESIMS spectrum $(\mathrm{m} / \mathrm{z}$, 383.3157 $[\mathrm{M}+\mathrm{H}]^{+}$, calcd. for $\left.\mathrm{C}_{23} \mathrm{H}_{43} \mathrm{O}_{4}{ }^{+}, 383.3156\right)$. The IR spectrum of 2 showed absorption bands characteristic of hydroxyl $\left(3458 \mathrm{~cm}^{-1}\right)$, ester $\left(1734 \mathrm{~cm}^{-1}\right)$, and ketone $\left(1715 \mathrm{~cm}^{-1}\right)$ groups. The UV absorption at $222 \mathrm{~nm}$ together with its IR and ${ }^{1} \mathrm{H}$ NMR spectroscopic data indicated a secobutanolide skeleton. ${ }^{910 \mathrm{~b}}$ Comparison of the ${ }^{1} \mathrm{H}$ NMR spectroscopic data of $\mathbf{2}$ with those of 1 revealed that the ${ }^{1} \mathrm{H}$ NMR of $\mathbf{2}$ exhibited additional signals at $\delta_{\mathrm{H}} 3.73(\mathrm{~s}, 3 \mathrm{H}, 1-\mathrm{OMe})$ and $\delta_{\mathrm{H}} 2.15\left(\mathrm{~s}, 3 \mathrm{H}, \mathrm{H}-3^{\prime}\right)$, but lacked the signals at $\delta_{\mathrm{H}} 4.96$ and $\delta_{\mathrm{H}} 4.72$ in 1 . This fact confirmed the presence of a methoxy and an acetyl group, and the absence of the $\alpha, \beta$-unsaturated- $\gamma$-lactone ring in 2 . In the HMBC spectrum, protons of the acetyl group at $\delta_{\mathrm{H}} 2.15\left(\mathrm{H}-3^{\prime}\right)$ showed correlations to an oxymethine group at $\delta_{\mathrm{C}} 73.5\left(\mathrm{C}-1^{\prime}\right)$. The methoxy protons at $\delta_{\mathrm{H}} 3.73$ (1-OMe) correlated with a carbonyl carbon at $\delta_{\mathrm{C}} 166.7$ (C-1), and the olefinic proton at $\delta_{\mathrm{H}} 7.08(\mathrm{t}, J=7.7 \mathrm{~Hz}, \mathrm{H}-3)$ exhibited cross peaks with both the oxymethine carbon $\left(\delta_{\mathrm{C}} 73.5\right.$, $\left.\mathrm{C}-1^{\prime}\right)$ and the carbonyl carbon $\left(\delta_{\mathrm{C}} 166.7, \mathrm{C}-1\right)$. Those correlations confirmed the assignment of a secobutanolide skeleton to 2 . By the same analysis used to characterize compound $\mathbf{1}$, the deshielded methylene group of 2 was assigned at C- 4 by the HMBC correlation between $\delta_{\mathrm{H}} 2.35(\mathrm{q}, J=7.6 \mathrm{~Hz}, 2 \mathrm{H}, \mathrm{H}-4)$ and the quaternary olefinic carbon at $\delta_{\mathrm{C}} 129.9(\mathrm{C}-2)$. Furthermore, the presence of an $E$ trisubstituted double bond was evident from the characteristic chemical shift of the olefinic proton at $\delta_{\mathrm{H}} 7.08(\mathrm{H}-$ 3 ), compared to that of known compounds with a $Z$ conformation $\left(\delta_{\mathrm{H}} 6.69\right){ }^{910 \mathrm{~b}}$

The positive optical activity $(+2.23, c 2.24, \mathrm{MeOH})$ of 2 indicated that $\mathrm{C}-1^{\prime}$ possessed the $S$ configuration. ${ }^{11 \text { abc }}$ Similarly to $\mathbf{1}$, the complete assignments of all protons and carbons of $\mathbf{2}$ (Table 1) were accomplished by further interpretation of its HMBC and HSQC spectra. From the above data, compound 2 was assigned as (2E)-2-[(1S)-1-hydroxy-2-oxo-propyl]-nonadec2-enoic acid methyl ester, and named macrocarpolide B.

The molecular formula of compound $3\left(\mathrm{C}_{21} \mathrm{H}_{38} \mathrm{O}_{4}\right.$, HRESIMS $m / z: 355.2856[\mathrm{M}+\mathrm{H}]^{+}$, calcd. for $\left.\mathrm{C}_{21} \mathrm{H}_{39} \mathrm{O}_{4}{ }^{+}, 355.2843\right)$ differed from that of 2 by $\mathrm{C}_{2} \mathrm{H}_{4}$, suggesting a two-carbon deletion in the side chain. Analysis of the UV, IR and ${ }^{1} \mathrm{H}$ NMR spectra revealed $\mathbf{3}$ to be a similar secobutanolide to 2 , with the same $E$ geometry of the trisubstituted double bond $\left[\delta_{\mathrm{H}} 7.08(\mathrm{t}, J=7.0 \mathrm{~Hz}, 1 \mathrm{H}, \mathrm{H}-\right.$ $3)$ ], but with two carbons less in the alkyl chain. Similarly to 2 , the $S$ configuration at $\mathrm{C}-1^{\prime}$ was deduced by the positive optical rotation value of +2.27 ( $c 0.88, \mathrm{MeOH}){ }^{11 \mathrm{abc}}$ The complete assignments of all protons and carbons of $\mathbf{3}$ (Table 2) were accomplished by interpretation of its HMBC and HSQC spectra. Therefore, compound $\mathbf{3}$ was assigned as (2E)-2-[(1S)-1-hydroxy2-oxo-propyl]-heptadec-2-enoic acid methyl ester, and named macrocarpolide $\mathrm{C}$.
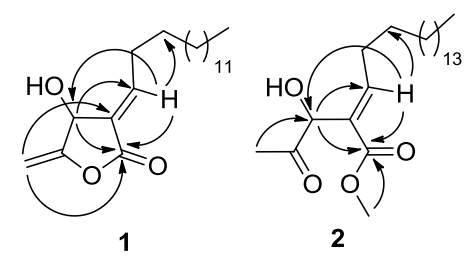

Figure 2. Key HMBC correlations of $\mathbf{1}$ and 2.

Compounds 1-5 showed good antiproliferative activities against the drug-sensitive $\mathrm{A} 2780$ ovarian cell line ${ }^{12}$ as previously described $^{13}$ using paclitaxel $\left(\mathrm{IC}_{50} 0.073 \pm 0.015 \mu \mathrm{M}\right)$ as the positive control. 
Table 2. ${ }^{1} \mathrm{H}$ and ${ }^{13} \mathrm{C}$ NMR data for compounds $\mathbf{2}$ and $\mathbf{3} .{ }^{\mathrm{a}}$

\begin{tabular}{|c|c|c|c|c|}
\hline & \multicolumn{2}{|r|}{2} & \multicolumn{2}{|c|}{3} \\
\hline Posn & $\delta_{\mathrm{H}}^{\mathrm{b}}$ & $\delta_{\mathrm{c}}^{\mathrm{c}}$ & $\delta_{\mathrm{H}}^{\mathrm{b}}$ & $\delta_{c}^{c}$ \\
\hline 1 & & $166.7(\mathrm{C})$ & & $166.7(\mathrm{C})$ \\
\hline 2 & & $129.9(\mathrm{C})$ & & $129.9(\mathrm{C})$ \\
\hline 3 & $7.08 \mathrm{t}(7.7)$ & $149.3(\mathrm{CH})$ & $\begin{array}{l}7.08 \mathrm{t} \\
(7.0)\end{array}$ & $149.3(\mathrm{CH})$ \\
\hline 4 & $2.35 \mathrm{q}(7.6)$ & $28.9\left(\mathrm{CH}_{2}\right)$ & $\begin{array}{c}2.35 \mathrm{q} \\
(7.6)\end{array}$ & $28.9\left(\mathrm{CH}_{2}\right)$ \\
\hline 5 & $1.25-1.31$ & $28.4\left(\mathrm{CH}_{2}\right)$ & $1.26 \mathrm{br} \mathrm{s}$ & $28.4\left(\mathrm{CH}_{2}\right)$ \\
\hline 6 & $1.25-1.31$ & 29.8-29.5 $\left(\mathrm{CH}_{2}\right)$ & $1.26 \mathrm{br} \mathrm{s}$ & $\begin{array}{c}29.8-29.5 \\
\left(\mathrm{CH}_{2}\right)\end{array}$ \\
\hline 7 & $1.25-1.31$ & 29.8-29.5 $\left(\mathrm{CH}_{2}\right)$ & 1.26 br s & $\begin{array}{c}29.8-29.5 \\
\left(\mathrm{CH}_{2}\right)\end{array}$ \\
\hline 8 & $1.25-1.31$ & 29.8-29.5 $\left(\mathrm{CH}_{2}\right)$ & 1.26 br s & $\begin{array}{c}29.8-29.5 \\
\left(\mathrm{CH}_{2}\right)\end{array}$ \\
\hline 9 & $1.25-1.31$ & 29.8-29.5 $\left(\mathrm{CH}_{2}\right)$ & 1.26 br s & $\begin{array}{c}29.8-29.5 \\
\left(\mathrm{CH}_{2}\right)\end{array}$ \\
\hline 10 & $1.25-1.31$ & 29.8-29.5 $\left(\mathrm{CH}_{2}\right)$ & 1.26 br s & $\begin{array}{c}29.8-29.5 \\
\left(\mathrm{CH}_{2}\right)\end{array}$ \\
\hline 11 & $1.25-1.31$ & 29.8-29.5 $\left(\mathrm{CH}_{2}\right)$ & $1.26 \mathrm{br} \mathrm{s}$ & $\begin{array}{c}29.8-29.5 \\
\left(\mathrm{CH}_{2}\right)\end{array}$ \\
\hline 12 & $1.25-1.31$ & 29.8-29.5 $\left(\mathrm{CH}_{2}\right)$ & $1.26 \mathrm{br} \mathrm{s}$ & $\begin{array}{c}29.8-29.5 \\
\left(\mathrm{CH}_{2}\right)\end{array}$ \\
\hline 13 & $1.25-1.31$ & $29.8-29.5\left(\mathrm{CH}_{2}\right)$ & 1.26 br s & $\begin{array}{c}29.8-29.5 \\
\left(\mathrm{CH}_{2}\right)\end{array}$ \\
\hline 14 & $1.25-1.31$ & 29.8-29.5 $\left(\mathrm{CH}_{2}\right)$ & 1.26 br s & $\begin{array}{c}29.8-29.5 \\
\left(\mathrm{CH}_{2}\right)\end{array}$ \\
\hline 15 & $1.25-1.31$ & 29.8-29.5 $\left(\mathrm{CH}_{2}\right)$ & $1.26 \mathrm{br} \mathrm{s}$ & $32.1\left(\mathrm{CH}_{2}\right)$ \\
\hline 16 & $1.25-1.31$ & 29.8-29.5 $\left(\mathrm{CH}_{2}\right)$ & $1.26 \mathrm{br} \mathrm{s}$ & $\begin{array}{c}29.8-29.5 \\
\left(\mathrm{CH}_{2}\right)\end{array}$ \\
\hline 17 & $1.25-1.31$ & $32.1\left(\mathrm{CH}_{2}\right)$ & $\begin{array}{l}0.88 \mathrm{t} \\
(7.0)\end{array}$ & $14.3\left(\mathrm{CH}_{3}\right)$ \\
\hline 18 & $1.25-1.31$ & $22.8\left(\mathrm{CH}_{2}\right)$ & & \\
\hline 19 & $0.88 \mathrm{t}(7.0)$ & $14.3\left(\mathrm{CH}_{3}\right)$ & & \\
\hline $1^{\prime}$ & $\begin{array}{c}4.90 \text { brd } \\
(4.9)\end{array}$ & $73.5(\mathrm{CH})$ & $4.90 \mathrm{brs}$ & $73.5(\mathrm{CH})$ \\
\hline $2^{\prime}$ & & 206.2 (C) & & $206.2(\mathrm{C})$ \\
\hline $3^{\prime}$ & $2.15 \mathrm{~s}$ & $25.0\left(\mathrm{CH}_{3}\right)$ & $2.15 \mathrm{~s}$ & $25.0\left(\mathrm{CH}_{3}\right)$ \\
\hline $\begin{array}{c}1- \\
\mathrm{OMe}\end{array}$ & $3.73 \mathrm{~s}$ & $52.2\left(\mathrm{CH}_{3}\right)$ & $3.73 \mathrm{~s}$ & $52.2\left(\mathrm{CH}_{3}\right)$ \\
\hline
\end{tabular}

${ }^{\mathrm{a}}$ Assignments based on analysis of 2D NMR spectra.

${ }^{\mathrm{b}}$ Data $(\delta)$ measured at $500 \mathrm{MHz}$; brs = broad singlet, dd= doublet of doublets, $\mathrm{dt}=$ doublet of triplets. $J$ values are in $\mathrm{Hz}$ and are omitted if the signals overlapped as multiplets. The overlapped signals were assigned from HSQC and $\mathrm{HMBC}$ spectra without designating multiplicity.

\section{References and notes}

1. Biodiversity Conservation and Drug Discovery in Madagascar, Part 63. For Part 62, see Liu, Y.; Young, K.; Rakotondraibe, L. H.; Brodie, P. J.; Wiley, J. D.; Cassera, M. B.; Callmander, M. W.; Rakotondrajaona, R.; Rakotobe, E.; Rasamison, V. E.; TenDyke, K.; Shen, Y.; Kingston, D. G. I. Antiproliferative Compounds from Cleistanthus boivinianus from the Madagascar Dry Forest. J. Nat. Prod. submitted for publication December 17, 2014

2. (a) Harinantenaina, L.; Brodie, P. J.; Maharavo, J.; Bakary, G.; TenDyke, K.; Shen, Y.; Kingston, D. G. I. Bioorg. Med. Chem. 2013, 21, 2912; (b) Kingston, D. G. I. J. Org. Chem. 2008, 73, 3975.

3. (a) Rohwer, J. G. Syst. Bot. 2000, 25, 60; (b) van der Werff, H. Adansonia, sér. 3, 2013, 35, 235.

4. $\quad$ Coelho de Souza, G.; Haas, A. P. S.; von Poser, G. L.; Schapoval, E. E. S.; Elisabetsky, E. J. Ethnopharmacol. 2004, 90, 135.

5. (a) Destryana, R. A.; Young, D. G.; Woolley, C. L.; Huang, T.-C.; Wu, H.-Y.; Shih, W.-L. J. Am. Oil Chem. Soc. 2014, 91, 1531; (b) de Camargo, M. J.; Miranda, M. L. D.; Kagamida, C. M.; Rodrigues, E. D.; Garcez, F. R.; Garcez, W. S. Quim. Nova 2013, 36, 1008; (c) Garett, R.; Romanos, M. T. V.; Borges, R. M.; Santos, M. G.; Rocha, L.; da Silva, A. J. R. Rev. Bras. Farmacogn. 2012, 22, 306;
'Data ( $\delta$ ) measured at $125 \mathrm{MHz}$; $\mathrm{CH}_{3}, \mathrm{CH}_{2}, \mathrm{CH}$, and $\mathrm{C}$ multiplicities were determined by HSQC experiment.

Their $\mathrm{IC}_{50}$ values were $2.57 \pm 0.12(\mathbf{1}), 1.98 \pm 0.23$ (2), 1.67 \pm 0.05 (3), $2.43 \pm 0.41$ (4), and $1.65 \pm 0.44 \mu \mathrm{M}$ (5). The similar IC $_{50}$ values for the five compounds suggests that they have a similar maechanism of action, possibly as Michael acceptors.

\section{Acknowledgments}

This project was supported by the Fogarty International Center, the National Cancer Institute, the National Institute of Allergy and Infectious Diseases, the National Institute of Mental Health, the National Institute on Drug Abuse, the National Heart Lung and Blood Institute, the National Center for Complementary and Alternative Medicine, the Office of Dietary Supplements, the National Institute of General Medical Sciences, the Biological Sciences Directorate of the National Science Foundation, and the Office of Biological and Environmental Research of the U.S. Department of Energy under Cooperative Agreement U01 TW00313 with the International Cooperative Biodiversity Groups. This project was also supported by the National Research Initiative of the Cooperative State Research, Education and Extension Service, USDA, Grant \#2008-3562104732. This support is gratefully acknowledged. Work at Virginia Tech was supported by the National Science Foundation under Grant CHE-0722638 for the purchase of the Agilent 6220 mass spectrometer. We thank Mr. B. Bebout for obtaining the mass spectra. Fieldwork essential for this project was conducted under a collaborative agreement between the Missouri Botanical Garden and the Parc Botanique et Zoologique de Tsimbazaza and a multilateral agreement between the ICBG partners, including the Centre National d'Application des Recherches Pharmaceutiques. We thank Stéphan Rakotonandrasana, Richard Randrianaivo, Armand Andriatsarafara, and Nambinintsoa Rakotonjanahary for assistance with plant collection, and we gratefully acknowledge courtesies extended by the Government of Madagascar (Ministère des Eaux et Forêts).

(d) Yamaguchi, M. U.; Garcia, F. P.; Cortez, D. A. G.; Ueda-Nakamura, T.; Filho, B. P. D.; Nakamura, C. V. Antonie Van Leeuwenhoek 2011, 99, 507; (e) Garcez, F. R.; da Silva, A. F. G.; Garcez, W. S.; Linck, G.; Matos, M. d. F. C.; Santos, E. C. S.; Queiroz, L. M. M. Planta Med. 2011, 77, 383; (f) Castro, R. D.; Lima, E. O. Rev. Bras. Plant. Med. 2011, 13, 203; (g) Cuca, L. E.; Leon, P.; Coy, E. D. Chem. Nat. Compd. 2009, 45, 179.

6. Seki, K.; Sasaki, T.; Wano, S.; Haga, K.; Kaneko, R. Phytochemistry 1995, 40, 1175.

7. Anderson, J. E.; Ma, W.; Smith, D. L.; Chang, C. J.; McLaughlin, J. L. J. Nat. Prod. 1992, 55, 71.

8. $\quad$ Cheng, H.-I.; Lin, W.-Y.; Duh, C.-Y.; Lee, K.-H.; Tsai, I.L.; Chen, I.-S. J. Nat. Prod. 2001, 64, 1502.

9. $\quad$ Cheng, M.-J.; Tsai, I.-L.; Lee, S.-J.; Jayaprakasam, B.; Chen, I.-S. Phytochemistry (Elsevier) 2005, 66, 1180.

10. (a) Martinez V, J. C.; Yoshida, M.; Gottlieb, O. R. Phytochemistry 1981, 20, 459; (b) Tsai, I.-L.; Hung, C.-H.; Duh, C.-Y.; Chen, I.-S. Planta Med. 2002, 68, 142.

11. (a) Chen, C.-Y.; Chen, C.-H.; Wong, C.-H.; Liu, Y.-W.; Lin, Y.-S.; Wang, Y.-D.; Hsui, Y.-R. J. Nat. Prod. 2007, 70, 103; (b) Kuo, S.-Y.; Hsieh, T.-J.; Wang, Y.-D.; Lo, W.-L.; Hsui, Y.-R.; Chen, C.-Y. Chem. Pharm. Bull. 2008, 56, 97; (c) Tanaka, H.; Nakamura, T.; Ichino, K.; Ito, K. Phytochemistry 1989, 28, 1905. 
12. Louie, K. G.; Behrens, B. C.; Kinsella, T. J.; Hamilton, T. C.; Grotzinger, K. R.; McKoy, W. M.; Winker, M. A.; Ozols, R. F. Cancer Res. 1985, 45, 2110.
13.

Cao, S.; Brodie, P. J.; Miller, J. S.; Randrianaivo, R.; Ratovoson, F.; Birkinshaw, C.; Andriantsiferana, R.; Rasamison, V. E.; Kingston, D. G. I. J. Nat. Prod. 2007, 70,679 . 


\section{Graphical Abstract}

\begin{tabular}{|c|c|}
\hline $\begin{array}{l}\text { Antiproliferative Compounds from Ocotea } \\
\text { macrocarpa from the Madagascar Dry Forest }\end{array}$ & Leave this area blank for abstract info. \\
\hline \multicolumn{2}{|c|}{$\begin{array}{l}\text { Yixi Liua, Emily Cheng }{ }^{\mathrm{a}} \text {, L. Harinantenaina Rakotondraibe }{ }^{\mathrm{a}, \mathrm{f}} \text {, Peggy J. Brodie }{ }^{\mathrm{a}} \text {, Jessica D. Wiley }{ }^{\mathrm{b}} \text {, Maria B. } \\
\text { Cassera }^{\mathrm{b}} \text {, Wendy Applequist }{ }^{\mathrm{c}} \text {, Chris Birkinshaw } \\
\text { E. Rasamison }{ }^{\mathrm{e}} \text { and David G. I. Kingston }{ }^{\mathrm{a}} *\end{array}$} \\
\hline
\end{tabular}

